\title{
Choice of Learning Styles among Tertiary Students in the Tamale Metropolis
}

\author{
Mohammed Bello Zuberu, Ibrahim Mohammed Gunu*, Issaka Cecilia Alimatu \\ Faculty of Education, University for Development Studies, Ghana
}

Copyright $\subseteq 2019$ by authors, all rights reserved. Authors agree that this article remains permanently open access under the terms of the Creative Commons Attribution License 4.0 International License

\begin{abstract}
The study sought to examine the nature of students learning style in Ghanaian universities. Descriptive-interpretive survey was used for the study. In all a sample of 84 was randomly selected from a population of 252. The instrument used for data collection was a self-constructed Learning Styles questionnaire (SLSSI), which contained both closed and open-ended items. The instrument was adopted and modified to fit the Ghanaian context. Cronbach Alpha coefficient was instrumental in measuring the validity and reliability of the instrument. The statistical tools used in the analysis of the data were frequencies and the percentages. The qualitative data were grouped according to themes for their emergent patterns. Findings of the research suggest that students are both holistic and serial learners. Their learning patterns are mainly determined by teaching methodologies and conditions of learning. As such participants can be described as both deductive and inductive learners who need to gain insight into the bigger picture, global perspective of a phenomenon before narrowing to a specific concept. The study also reveals that the most frequently used sense organ among students is the visual references (Reading and graphic displays) 90.4\% and verbal explanation of ideas as well as hand on task (practical). The article therefore recommends the universities in collaboration with national government must provide appropriate facilities and suitable learning environment as well as ensure regular in-service training on different learning styles and their implications for university lecturers.
\end{abstract}

Keywords Learning Styles, Tertiary Students, Individual Differences

\section{Introduction}

\subsection{Background to the Study}

The term learning style in educational context is often used interchangeably by some researchers to denote cognitive style of learning (see Hayes \& Allinson, 1998). But some researchers indicate that the concept learning style is a comprehensive terminology which includes the cognitive learning style, affective style, and physiological style domains (see Terry, 2002; Rayner \& Riding, 1997). Cognitive learning style includes the various means by which human senses interrelate with the environment to receive stimuli and thence process it into meaningful information (see Hayes \& Allinson, 1998; Terry, 2002; Rayner \& Riding, 1997; Hoover \& Marshall, 1998). Affective learning style is associated with the emotional support, values and feelings of the student regarding the learning content (see Dunn, 2000; Chory \& Mccroskey, 1999). Physiological style domain considers environmental factors such as sitting arrangement, temperature and lightning in the learning environment that affect the way people learn (Dunn, 2000).

Learning styles refer to behavioural and attitudinal factors that stimulate learning in every circumstance (Hayes \& Allinson, 1998; Terry, 2002; Dunn, 2000; Rayner \& Riding, 1997; Hoover \& Marshall, 1998). The interactions between the way students learn and how the teachers teach are largely influenced by different learning styles. Learning style guides and determines our behaviour and how we tackle our daily activities (Hayes \& Allinson, 1998; Terry, 2002; Dunn, 2000; Rayner \& Riding, 1997; Hoover \& Marshall, 1998). In the processes of learning, learners prefer using different methods of managing, processing, and interacting with information. These methods, processes and preferences are described as Learning Styles (Şirin \& Güzel, 2006; Terry, 2002; Rayner \& Riding, 1997). Every human organism is special and has a favourable and a unique learning style. This can be a result of external determiners like the culture, the personal experiences, and the developments of the person (Dunn, 2000). In this sense all individuals have preferred means of perceiving, organizing and retaining information.

The styles of learning of individuals is significant in the educational enterprise as it relates to how individuals perceive, relate with, and respond to their learning 
environments bringing out issues regarding students different learning styles. Generally, learning style facilitates the natural pattern of obtaining and making sense of information in the process of learning. There have been many researches on the concept, but there is no consensus regarding its definition; but an important consideration is that individuals have differences in how they learn (James \& Gardner, 1995; Terry, 2002; Rayner \& Riding, 1997).

The learning style of individuals is based on the issues regarding how information is gathered, processed and applied when it is required. Individual differences amongst students often influence both their learning and their academic attainment (Riding, 2005; Terry, 2002; Rayner \& Riding, 1997). When students are exposed to a teaching and learning style that corresponds with their learning style, they can potentially achieve high academic success (Felder, Felder, \& Dietz, 2002; Rayner \& Riding, 1997; Dunn \& Griggs, 2000). Drawing on the individual differences, it is significant to mention that there are many factors that influence students' learning styles in academic context. These factors include: gender of the person, age, the processing capacity of the brain, culture/ ethnic background (see also Bush and Middlewood, 2005; Dunn, 2000; Dunn \& Griggs, 2000), creative thinking skills, past experiences, environmental factors (including teaching methods and educational settings), among others (Stoll and Fink, 1996; Honigsfeld, 2001; Philbin et al., 1995; Slater et al., 2007).

Contextually, this study regarding learning styles in Ghanaian Universities is significant because Teaching and Learning are the core businesses of our higher institutions of learning (see Wolf, 2002). In keeping with this notion, knowing individuals desired learning styles will help students achieve their learning goals and increase efficiency of the learning outcome (Dunn, 2000; Dunn \& Griggs, 2000). In this sense consistence and reorganisation of the teaching methods in line with the characteristics of the learners will be desirable in equipping the students the needed skills, values and attitudes (Ozgan \&Alkan, 2012; Rayner \& Riding, 1997; Gunu, 2018).

This demonstrates the fact that the construction of better learning environment and experiences for students in the Ghanaian universities is very significant hence the need for this research in Ghanaian context. Universities play a major role in the nation's economy. For instance, Wolf (2002) notes that universities make two major contributions. These are; universities are responsible for the education and training of professionals like lawyers, doctors, engineers, teachers, designers and the likes who are major players in the economy. This shows that the academic training in the universities has an obvious effect on people's cognitive skills. The activities of these professionals make a significant contribution to the nation's GDP and general economic life. Secondly, universities play an important role as the generator of scientific and technological innovations. These roles have a significant commercial relevance hence economic growth. In the following the problem statement is presented.

\subsection{Statement of the Problem}

Even though there are lots of evidences on the differences regarding individual thinking and means of processing information successfully, the specific Ghanaian context is provided in this research. The need to provide scientific evidence to support the debate on learning styles presents a justification for this study. Students will learn best if taught with a technique that is suitable for their learning style (Rayner \& Riding, 1997; Pashler et al, 2008; Dunn \& Griggs, 2000). The current state of research in respect of students learning styles or methods serve as a motivating factor for the researchers to explore the different learning styles of students in one of the Universities in Ghana and to examine the associated factors motivating the choice of a given learning style. An awareness of the students' learning styles could potentially facilitate the adaption of suitable techniques and methods to correspond with the students' inclination (Alfonseca et. al., 2006; Rayner \& Riding, 1997; Dunn \& Griggs, 2000). These efforts will promote effective teaching practices and techniques that best suit the students learning styles.

\section{Research Questions}

The following research questions were addressed:

1. What is the nature of students learning style?

2. Under what conditions do students learn best?

3. What teaching and learning approaches facilitate students understanding of concepts?

\section{Brief Review of the Related Literature}

Studies in learning styles reveal that designing and delivering learning materials according to personal characteristics helps in enhancing the attainment of learning goals (Fearing \& Riley, 2005; Dunn \& Griggs, 2000). Depending on individual differences, some people grasp information presented in the form of facts, numbers, steps, theories and mathematical models better than any other form, whilst others prefer visual channels like pictures, diagrams, and simulations to create better understanding. In some cases, some other individuals prefer oral and written information (Dunn \& Dunn, 2000; Dunn \& Griggs, 2000). The lack of consensus among researchers regarding the usefulness of learning styles makes the categorisation of these learning styles much more complex (see Smith \& Ragan, 1999; Kolb \& Kolb, 2005; Schellens and Valcke, 2000; Neuhauser, 2002).

In another context Dunn \& Dunn (2000) identify four 
ways of learning such as visual, auditory, kinaesthetic and tactile claiming that they are based on the main sensory systems in people. Thus, they believe one or two of the sensory systems help in determining one's dominant styles of learning even though may vary depending on the task. Students' learning attainments are thus greatly influenced by certain fixed features (Dunn \& Griggs 2003).

From the above, Dunn and Dunn (1978) notes that people who differ in learning styles possess unique preferences when undertaken different learning activities. In this sense, researchers and practitioners proposed models and instruments to help colleague researchers' measure learning styles.

Several researchers like Akdemir and Koszalkab, 2008; Chory, \& Mccroskey, 1999; Cuthbert, 2005; Hayes, \& Allinson, 1998; Hoover, \& Marshall, 1998; Shaw (2012) examined the relationship between instructional strategies and learning styles. These studies have established that there is a stronger relationship for various learning styles which made students to achieve their learning outcome. Drawing of these researchers these models and instruments have been the backbone of this research. However, Neuhauser (2002) and Schellens \& Valcke (2000) did not find any relationship between learning style and the performance of the students. This brief presentation of the literature demonstrates the critical relationship between teaching strategies and learning styles. In the following the methodological position of the article is presented.

\section{Methodology}

\subsection{Study Design}

The descriptive-interpretive survey design was adopted for the study in order to establish the students' learning styles. A survey research designs are mainly used to investigate opinions and preferences as in the case of students' learning styles (Aldridge and Levine, 2001; de Vaus, 2001, 2012; Bryman, 2016). Aldridge and Levine (2001) note that Survey research allows critical variables like preferences and opinions of individuals to be collected and examined.

\subsection{Population Sample and Sampling Procedure}

Eighty-four (84) University students out of a total of 252 from different programme of the same year group from the same faculty were selected. Consisting of 56 boys and 28 girls drawn from the university, all the selected participants answered the self-constructed Learning Styles Survey instrument (SLSSI). Ten of these participants were selected for interviews. The criteria for selection were based on the top $5 \%$ performance in the various programmes of study.

\subsection{Instrumentation}

The data was collected using self-constructed Learning Styles Survey instrument (SLSSI). This instrument contained 24 closed and open-ended questions focusing on the following learning styles issues of university students in Ghana. These critical issues include:

1. Conditions under which students learn best;

2. Teaching and learning approaches that facilitate students understanding of concepts;

3. Examining the relationship between time spent on task and students learning outcomes.

This type of questionnaire was developed in the Likert scale mode. The items were revised to suit the Ghanaian context. The main objective was to explore the effects of the learning styles on students' total academic experience and attainment. In this sense an analysis was done on the chosen sample $(n=84)$.

To evaluate its effectiveness in terms of validity and reliability, the instrument was subjected to test using the Cronbach Alpha (result) this was a promising validity.

\section{Results and Discussion}

Table 1 indicates that there are more male in the study than female.

Table 1. Gender

\begin{tabular}{ccc}
\hline Gender & Frequency & Perception \\
\hline Male & 56 & 66.7 \\
\hline Female & 28 & 33.3 \\
\hline Total & $\mathbf{8 4}$ & $\mathbf{1 0 0 . 0}$ \\
\hline
\end{tabular}

Table 2 indicates that the participants are coming from different programmes. Most of the participants 39.3\% pursue degree progamme in development education.

Table 2. Programme of Study

\begin{tabular}{ccc}
\hline Programme of Study & Frequency & Percentage \\
\hline Diploma students & 5 & 6.0 \\
\hline Degree 1 & 33 & 39.3 \\
\hline Degree 2 & 18 & 21.4 \\
\hline Degree 3 & 28 & 33.3 \\
\hline Total & $\mathbf{8 4}$ & $\mathbf{1 0 0 . 0 0}$ \\
\hline
\end{tabular}

\section{Research Question 1: What is the nature of students} learning style?

This research question examined the nature of students learning styles. Simple percentages were used to group students' responses. Table 3 below presents information on the nature of students learning style.

It can be seen from Table 3 that student are divided over the descriptions of their learning styles, while $52.1 \%$ describe the nature of their learning style as "students should have a bigger picture, global perspective before 
narrowing to a specific concept", the other $47.9 \%$ thought that students should narrow their focus to a well-defined, sequential steps. This suggest that many students are holistic than serial learners. Table 4 provides further highlight on the nature of students learning styles.

Table 3. Nature of student learning style

\begin{tabular}{lcc}
\hline \multicolumn{1}{c}{ Description of learning style } & Frequency & Percentage \\
\hline $\begin{array}{l}\text { The need for students to have a bigger } \\
\text { picture, global perspective before } \\
\text { narrowing to a specific concept }\end{array}$ & 48 & 52.1 \\
\hline $\begin{array}{l}\text { The need for a narrow focus to a } \\
\text { well-defined, sequential steps (slow } \\
\text { development of the overall picture) }\end{array}$ & 34 & 47.9 \\
\hline Total & $\mathbf{8 4}$ & $\mathbf{1 0 0 . 0}$ \\
\hline
\end{tabular}

\subsection{Students Mode of Acquiring New Information}

Analysis of the open-ended responses provided by the participants suggests that students acquire new information from several platforms and one of these platforms is the mobile phone and internet or the social media. One of such participants said: "I acquire new information through researching on the internet and contacting some current books". Other learning platforms for students are the investigation and interaction with others as well as reading books from the library and other sources including lectures and research. One of the participants said: "I learnt through my own research and also asking for assistance from my friends". Another participant who shared similar experience said: "I acquire new information by learning and through interactions with friends in and outside campus".

There are other ways by which students acquire new information, some of such sources include the notice board, lecture notes and from friends as well as through group discussion. One of such students remarked: "I acquire information from lecture materials, library and mostly on the internet". Another participant explained: "I acquire new information through social media and verbal interactive communication with friends as well as facilitation of lecturers, books and the social media". Table 4 provides further information on students learning styles.

Students' preferred learning styles are varied depending on the characteristics of the students. Table 4 indicates that $92.5 \%$ of the participants prefer extended reading on a topic on their own than being lectured.

Table 4. Students preferred learning style

\begin{tabular}{ccccc}
\hline & Yes & \multicolumn{2}{c}{ No } \\
\hline & Frequency & Percentage & Frequency & Percentage \\
\hline Extended reading on a topic & 74 & 92.5 & 6 & 7.5 \\
\hline When information is projected & 56 & 70.9 & 23 & 29.1 \\
\hline White board illustrations & 68 & 87.2 & 10 & 12.8 \\
\hline Private reading & 76 & 92.7 & 6 & 7.3 \\
\hline Group discussions & 70 & 87.5 & 10 & 12.5 \\
\hline Classroom lectures & $\mathbf{7 3}$ & $\mathbf{9 2 . 4}$ & $\mathbf{6}$ & $\mathbf{7 . 6}$ \\
\hline
\end{tabular}

Table 5. Social versus Individual learning styles

\begin{tabular}{ccccc}
\hline Nature of students learning & Very often & Often & Seldom & Never \\
\hline I like working with others & $41(50.6)$ & $40(49.4)$ & - & - \\
\hline I learn best when I engage in discussions & $42(51.9)$ & $38(46.9)$ & $1(1.2)$ & - \\
\hline I share information with other students & $45(56.3)$ & $31(38.8)$ & $4(5.0)$ & - \\
\hline I am always conscious about my grades & $62(76.5)$ & $14(17.3)$ & $5(6.2)$ & - \\
\hline I always feel that I should do better than my peers & $43(53.1)$ & $27(33.3)$ & $7(8.6)$ & $4(4.9)$ \\
\hline I always enjoy attending lectures & $63(77.8)$ & $14(17.3)$ & $3(3.7)$ & $1(1.2)$ \\
\hline I always restraint myself from class activities & $8(9.9)$ & $30(37.0)$ & $9(11.1)$ & $34(42.0)$ \\
\hline I have no interest in learning & & & &
\end{tabular}


Further analysis of the participants learning styles in Table 5 reveals that almost $100 \%$ of the participants either very often or often enjoy working with others and even learn best when they engage in group discussions. Again, $95 \%$ of the participants always or sometimes share information with other students. Further analysis from table 6 shows that majority (92\%) of the participants are always conscious about their grades and enjoy attending lectures. This is an indication that participants are generally social learners. They depend on each other and concerned about what others think about them.

Students have different times which are conducive for them to learn. Analyses of the open-ended responses given by the students suggest that the majority of the students prefer studying at night and in the morning. For some students, they study when examination or midterm is approaching. Other students prefer studying when they have peace of mind. One of such students wrote "I study when my mind is ready to learn, and the learning materials are available ...". Some other students' study during group discussion or when they have group discussion ahead of them.

Research Question 2: Under what conditions do students learn best?

This research question sought to find out the condition under which students learn best. Quantitative data was used to answer this question. Simple percentages were used to group students' responses. Table 6 presents information on the conditions under which students learn best.

There is no consensus on the conditions under which students learn. Table 6 shows that $72.9 \%$ of the students are sometimes comfortable with the current learning environment in the university. About $65 \%$ of the students indicate that their learning style is sometimes compatible with the learning environment in the university and $51.2 \%$ of the participants admitted that the learning environment influences their learning while $51.2 \%$ learn best when they are with others.

\section{Research Question 3: What teaching and learning approaches facilitate students understanding of concepts?}

This research question explored the learning styles students use. Quantitative data was used to answer this question. Simple percentages were used to group students' responses.

Analysis of the participants learning styles in Table 7 reveals that $51.2 \%$ of the participants often need guidance on new concepts taught in class before they can make meaning out of it. A hand full (11\%) seldom or never sought guidance of teachers on a new concept.

Table 7 also shows that about $81 \%$ of the participants either very often or often need direction on how to go about new concepts taught in class. Similarly, $93 \%$ of the participants either very often or often need a lot of examples before they can understand new concepts taught in class and about $95 \%$ either very often or often concerned about how lecturers present new concepts. This indicates that majority of the participants are dependent learners. They need a lot of exposures in order to internalise concepts. Only few of them are independent learners.

Table 6. Conditions under which students learn

\begin{tabular}{ccccc}
\hline Conditions & Always & Sometimes & Seldom & Never \\
\hline I am comfortable with learning environment & $18(21.2)$ & $62(72.9)$ & $5(5.9)$ & - \\
\hline Learning environment influences my learning & $43(51.2)$ & $35(41.7)$ & $4(4.8)$ & $2(2.4)$ \\
\hline My learning style is compatible with the learning environment & $18(22.2)$ & $53(65.4)$ & $5(5.7)$ & $5(5.7)$ \\
\hline I learn best in serene environment & $42(50.6)$ & $32(38.6)$ & $6(7.2)$ & $3(3.6)$ \\
\hline When I am with others, I learn best & $31(36.9)$ & $43(51.2)$ & $3(3.6)$ & $7(8.3)$ \\
\hline When I am a lone, I learn best & $40(47.6)$ & $37(44.0)$ & $4(4.8)$ & $3(3.6)$ \\
\hline
\end{tabular}

Table 7. Dependent and Independent learning styles

\begin{tabular}{ccccc}
\hline Nature of students learning & Very often & Often & Seldom & Never \\
\hline I often need guidance on a new concept taught in class & $31(37.8)$ & $42(51.2)$ & $7(8.5)$ & $2(2.4)$ \\
\hline I often need direction on how to go about new concepts taught in class & $25(30.2)$ & $42(51.2)$ & $11(13.4)$ & $4(4.9)$ \\
\hline I often need a lot of examples before I can understand new concepts taught in class & $28(34.1)$ & $49(59.8)$ & $2(2.4)$ & $3(3.7)$ \\
\hline I often depend on the lecturer for information on new concepts taught in class & $22(27.2)$ & $51(63.0)$ & $6(7.4)$ & $2(2.5)$ \\
\hline I am often concerned about how lecturers present new concepts & $54(65.1)$ & $26(31.3)$ & - & $3(3.6)$ \\
\hline
\end{tabular}


There are different senses individuals use to attend to stimuli. Analysis of Table 8 reveals that almost $62 \%$ of the students frequently use the sense of hearing in their learning. This also followed by the sight. However, sense of smell and taste are sparingly used in learning.

Table 8. The Frequently used sense organ in students learning

\begin{tabular}{ccc}
\hline Sense Organs & Frequency & Percentage \\
\hline Hearing & 52 & 61.9 \\
\hline Seeing & 30 & 35.7 \\
\hline Smelling & 1 & 1.2 \\
\hline Tasting & 1 & 1.2 \\
\hline Total & $\mathbf{8 4}$ & $\mathbf{1 0 0 . 0}$ \\
\hline
\end{tabular}

Table 9 shows that the most frequently used sense organ among students is the visual references (reading and graphic displays) $90 \%$ and the least used sense organ in learning among students is the auditory presentation (description of the subject Matter).

Table 9. Sense Organs students rely on, during learning

\begin{tabular}{|c|c|c|c|c|}
\hline & Yes & & No & \\
\hline $\begin{array}{l}\text { Sense organs students often } \\
\text { use in learning }\end{array}$ & Freq. & $\%$ & Freq. & $\%$. \\
\hline $\begin{array}{l}\text { Visual references (Reading } \\
\text { and graphic displays) }\end{array}$ & 66 & 90.4 & 7 & 9.6 \\
\hline $\begin{array}{l}\text { Verbal explanations of } \\
\text { some ideas }\end{array}$ & 64 & 87.7 & 9 & 12.3 \\
\hline Hand on the job (practicals) & 61 & 94.7 & 11 & 15.3 \\
\hline $\begin{array}{l}\text { Auditory presentation } \\
\text { (Description of the subject } \\
\text { matter) }\end{array}$ & 56 & 77.8 & 16 & 22.2 \\
\hline $\begin{array}{lr}\begin{array}{l}\text { Presenting } \\
\text { through } \\
\text { equations }\end{array} & \text { mathematical } \\
\end{array}$ & 28 & 41.2 & 40 & 58.8 \\
\hline
\end{tabular}

\subsection{The Influence of Past Experience on Learning Concept}

Analysing the open-ended responses participants provided, suggests that students previous experiences and background knowledge influences their learning style in several ways. For some participants their previous experience gives them encouragement to struggle for whom to be in future. In other words, their previous experience enables them set goals for themselves. One of such participants said: "My past experience influences my learning because when I look at where I started it always motivates me to learn".

For some other participants their previous experience helps them to adopt new methods of learning as compared to the past especially when they realise that the previous approach is not yielding any positive results. Other participants said that their previous experiences have effects on their mindset and emotions which need to be relaxed when learning. According to them, a lot of emotional problems make them feel bad. For others, in any learning situation they need to activate their previous knowledge, as they learn, they keep on reflecting about what they learn in relation to their pervious knowledge. One of such participants said: "I am able to relate to the past experience by learning process. I draw on past experience to understand things better".

Another participant said: "Experiences affect my readiness to learn in a sense that the knowledge I learnt previously helps me in other courses which makes understanding easier". "Past experience are applied to enhance effective learning and also to make comparisons to choose the best", "Experience of previous failures motivates me not to want to fail and therefore I learn hard in order not to fail". However, for some of the students their past experience does not influence their learning. One of such participants said: "My past experience does not affect my readiness to read".

\subsection{Mode of Evaluating Learning Style}

Analyses of the open-ended responses of the participants suggest that participants evaluate the effectiveness of their learning style in diverse ways. While others use time on task and performances as a yardstick to measure their performance, other evaluate the effectiveness of their learning style by setting questions before learning and answering the questions after learning. One of the participants who set questions before learning and answering the questions after learning said: "I always give my handout or books to my friend and he will be asking me the questions in the book and I will be answering". Another participant said:

"Actually, I evaluate the effectiveness of my study habit through the following: performance or grade in class, how I am able to recall, relate what I study in my daily life, how best I am able to explain whatever I study to my peers or colleagues in class".

Another participant said:

"I evaluate the effectiveness of my learning by trying to jot down relevant points after my study and try to explain in my own way. I also make sure I involve myself in group discussions to know whether what I have learnt has stickled or better still relate to the reality of my life".

Another participant said:

"My study habit I think best fits my situation because it has helped me in so many ways to understand some complex concepts through the help of my peers through group discussion"

Another participant said:

"I evaluate the effectiveness of my study habit through learning alone and group studies and discussion. I sometimes compare my study alone and group studies through test, assignments and end of trimester". 
Other modes by which participants evaluate the effectiveness of their learning styles is the categorisation in terms of ranking such as the very good, good etc.

\subsection{Reliability}

Cronbach Alpha or coefficient Alpha Reliability (Fokoue and Gunduz, 2015; Okada, K, 2015; Topala and Tomozii, 2014) was key in determining reliability in this research. It dealt with internal consistence reliability. In this sense it measures from .00 to 1.0. This kind of measurement indicates that 1.0 represents perfect consistency in measurement and .00 represents no consistence in measurement (see Fokoue and Gunduz, 2015; Okada, K, 2015; Topala and Tomozii, 2014). The reliability measurement in this research was .98 which means that $98 \%$ of the variance in the scores is reliable variance. It also means $0.02 \%$ is in error variance. This is a good reliability and consistence measurement as the error variance is low. The test follows each individual score from 9 items analysed using the SPSS. The statistical presentation is done below.

$$
\begin{gathered}
a=\frac{9(.862)}{(1+(9-1) .862} \\
a=\frac{7.758}{7.896}=.98
\end{gathered}
$$

\subsection{Key Findings}

1. From the analysis, it can be said that students are both holistic and serial learners who are largely influenced by teaching methodologies and conditions of learning. As such participants can be described as both deductive and inductive learners who need to gain insight into the bigger picture, global perspective of a phenomenon before narrowing to a specific concept. However, there are others who are inductive learners who need direct instruction on a narrow and a well-defined focused. In this sense the overall picture is developed logically and slowly.

2. The study found out that majority of the participants enjoy working with others and even learn best when they engage in group discussions. They always or sometimes share information with other students. In doing this, they are very conscious about their grades and enjoy attending lectures. This is an indication that participants are generally social learners. They depend on each other and concerned about what others think about them.

3. The study reveals that the most frequently used sense organ among students is the visual references (reading and graphic displays) $90.4 \%$ and verbal explanation of ideas as well as hand on task (practical), however, the least used sense organ in learning among students is the presentation of information through mathematical models and auditory presentation (description of the subject matter). The analysis made reveals that almost $62 \%$ of the students frequently use the sense of hearing in their learning. This also preceded by the sight. However, sense of smell and taste are sparingly used in learning.

4. Analysis of the participants learning styles in Table 4 reveals that $51.2 \%$ of the participants often need guidance on new concepts taught in class before they can make meaning out of it. Almost $11 \%$ seldom or never sought guidance of teachers on a new concept. The participants either very often or often need direction on how to go about new concepts taught in class. Participants either very often or often need a lot of examples before they can understand new concepts taught in class and about $95 \%$ either very often or often concerned about how lecturers present new concepts

\section{Discussion}

From the analysis made, students are divided over the issues of learning styles. While majority of them favoured deductive approach to learning by gaining insight into the bigger picture, global perspective before narrowing to a specific concept, others were in favour of inductive approach to learning by focusing on a narrow and a well-defined issue. In this sense, sequential steps are taken to develop the overall picture slowly, thoroughly and logically to create an understanding. The findings of this research corroborates Sun et al., (2008), Kolb and Kolb, (2005) \& Smith and Ragan, (1999) assertions that a significant number of learners focus on facts, figures, an engagement with theories and in some cases mathematical models, others prefer visual means like pictures, diagrams, and the likes to enhance their understanding.

Although, learners can either be holistic or serial, inductive or deductive, this does not mean such learners do not assimilate learning from tutors who are holistic or serialist. Learners can learn and retain learning from each of the styles. What it means is that learners are more likely to assimilate and retain learning best, if tutor's approaches and styles match with those of the students. There are some other learners who are inclined to oral than written. The absence of consensus among researchers regarding the significance of learning styles makes the categorisation of the learning styles very complex (see Kolb \& Kolb, 2005; Sun et al., 2008; Schellens and Valcke, 2000; Neuhauser 2002; Smith \& Ragan, 1999).

The study also found out that majority of the participants enjoy working with others and even learn best when they engage in group discussions. The study suggests that motivation changes depending on the class, the lecturer concerned and the specific day in context. Some of the students are self-motivated to learn, and others lack the needed motivation. A self-motivated student naturally enjoys learning on his/her own. 


\section{Limitations and Further Research}

The study is associated with some limitations. These limitations include the fact that the study did not consider the views of university lecturers and the auxiliary staff. The perspectives of these stakeholders would have been valuable in supporting the students to learn. Also, the study draws its sample from one faculty in the university even though they belonged to different programmes. This did not permit wider involvement of the students. In this sense, further research should seek to consider the views of students of the other programmes, lecturers and the auxiliary staff. Further research could also explore in-service training courses that can support teacher professional development to improve student learning.

\section{Conclusions}

The findings of the research suggest the teaching methodologies of lecturers are considered as significant part of the learning process in the University. In keeping with this view point, it is significant for the lecturers/instructors to estimate the processing techniques in order to make learning relatively suitable for the students. The lecturers should take cognisance of the fact that the majority of the students enjoy working with others and learn best when they engage in group discussions. However, a few of them learn better when learning alone. The skills to manage these differences of the students should be done through continuous professional development programmes by the universities.

\section{Recommendation}

1. Periodic or regular in-service training could be organised for university lecturers on different learning styles and their implications for teaching and learning so as to enable them guide and counsel students who are likely to be in dilemmas of learning.

2. University authorities need to liaise with the metropolitan and regional as well as the national government to provide lecture theatres and suitable conditions of learning to enhance students learning and induce positive learning outcomes.

3. Lectures and tutors need to individualise their teaching to commensurate the learning styles of their students by adopting teaching and learning strategies that facilitate students understanding of concepts.

\section{REFERENCES}

[1] Akdemir, O., \& Koszalka, T. A. (2008). Investigating the relationships among instructional strategies and learning styles in online environments. Computers \& Education, 50(4), 1451-1461.

[2] Aldridge, A. \& Levine K. (2001). Surveying the social world: Principles and practice in survey research. Buckingham: Open University Press.

[3] Alfonseca, A, Carro, R. martin, E. Ortigas, A \& Paredes, P. (2006). The impact of learning styles on student grouping for collaborative learning: A case study. User Model User-adap Inter 16 (3-4), 377- 401.

[4] Bryman, A. (2016). Social research methods (5th ed.). Oxford, UK: Oxford University Press

[5] Bush, T., \& Middlewood, D. (2005). Leading and managing people in education. London, England: Sage.

[6] Chory, R. M., \& Mccroskey, J. C. (1999). The relationship between teacher management communication style and affective learning. Communication Quarterly, 47(1), 1-11. doi:10.1080/01463379909370120

[7] Cuthbert, P. F. (2005). The student learning process: Learning styles or learning approaches teach. Higher Education, 10(2), 235-249.

[8] De Vaus, D. (2001) Research Design in Social Research. London: SAGE Publications.

[9] De Vaus, D. (2012) Analyzing social science data. London: London: SAGE.

[10] Dunn, R. (2000). 'Capitalizing on College Students' Learning Styles: Theory, Practice, and Research'. In R. Dunn \& S. A. Griggs. Practical approaches to using learning styles in higher education. Westport, Conn.: Bergin \& Garvey.

[11] Dunn, R. \& Griggs, S. A. (2000). 'Practical Approaches to Using Learning Styles in Higher Education: The How-to Steps'. In R. Dunn \& S. A. Griggs. Practical approaches to using learning styles in higher education. Westport, Conn.: Bergin \& Garvey.

[12] Dunn, R. S., \& Griggs, S. A. (2000). Practical approaches to using learning styles in higher education. Westport, Conn.: Westport, Conn.: Bergin \& Garvey.

[13] Dunn, R., \& Dunn, K. (1978). Teaching students through their individual learning styles: A practical approach. Reston, VA: Reston Publishing.

[14] Dunn, R. (2000). Learning styles: Theory, research, and practice. National Forum of Applied Educational Research Journal, 13(1), 3-22.

[15] Dunn, R. and Griggs, S.A. (2003), Synthesis of the Dunn and Dunn learning style model: Who, what, when, where, and so what?, Center for the Study of Learning and Teaching Styles, St John's University, New York, NY.

[16] Fearing, A., \& Riley, M. (2005). Graduate students' perceptions of online teaching and relationship to preferred learning styles. Medsurg Nursing, 14(6), 383-389.

[17] Felder, R. M., Felder, G. N., \& Dietz, E. J. (2002). The effects of personality on engineering student performance and attitudes. Journal of Engineering Education, 9(1), 3-17.

[18] Fokoue, E. and Gunduz, N. (2015). An 
Information-Theoretic Alternative to the Cronbach's Alpha Coefficient of Item Reliability.

[19] Gunu, M. I. (2018). Alternatives to School Exclusion in Ghana: Changing the Rhythm of Dealing with Truancy in Ghanaian High Schools. SAGE Open, 8(4), p.2158244018805361.

[20] Hayes, J., \& Allinson, C. W. (1998). Cognitive style and the theory and practice of individual and collective learning in organizations. Human Relations, 51(7), 847-871. doi: $10.1177 / 001872679805100701$

[21] Honigsfeld, A. M. (2001). A comparative analysis of the learning styles of adolescents from diverse nations by age, gender, academic achievement level and nationality. Ph.D dissertation, Dissert AbstrInt, 62, 969.

[22] Hoover, T. S., \& Marshall, T. T. (1998). Comparison of learning styles and demographic characteristics of students enrolled in selected animal science courses. Journal of Animal Science; Comparison of Learning Styles and Demographic Characteristics of Students Enrolled in Selected Animal Science Courses, 76(12), 3169-3173. doi: $10.2527 / 1998.76123169 \mathrm{x}$

[23] James W.B., Gardner D.L. (1995). Learning styles: Implications for distance learning. New Dir. Adult Contin. Educ. 67, 19-32.

[24] Kolb, A. Y., \& Kolb, D. A. (2005). Learning styles and learning spaces: enhancing experiential learning in higher education. Academy of Management Learning \& Education, $4(2), 193-212$.

[25] Neuhauser, C. (2002). Learning style and effectiveness of online and face-to-face instruction. American Journal of Distance Education, 76(2), 99-113.

[26] Okada, K. (2015). Bayesian meta-analysis of Cronbach's coefficient alpha to evaluate informative hypotheses. Research Synthesis Methods, 6(4), pp. 333-346.

[27] Ozgen, K., \& Alkan, H. (2012). The Relationship between Secondary School Pre-Service Mathematics Teachers' Skills in Problem Solving Dimensions and Their Learning Style Characteristics. Educational Sciences: Theory and Practice, 12(2), 1173-1181.

[28] Pashler, H., McDaniel, M., Rohrer, D. \& Bjork, R. (2008). Learning styles: concepts and evidence. Psychological Science in the Public Interest, 9, 105-119.

[29] Philbin, M., Meier, E., \& Huffmann, S. (1995). A survey of gender and learning styles. Sex Roles 7/8: 491.

[30] Philbin, M., Meier, E., Huffman, S. and Boverie, P., (1995). A survey of gender and learning styles. Sex Roles, 32(7/8), 485-494.

[31] Popescu, E. (2010). Adaptation provisioning with respect to learning styles in a Web-based educational system: An experimental study. Journal of Computer Assisted Learning, $26,243-257$.

[32] Rayner, S., \& Riding, R. (1997). Towards a categorisation of cognitive styles and learning styles. Educational Psychology, 17(1-2), 5-27. doi:10.1080/014434197017010 1

[33] Schellens, T., \& M. Valcke. 2000. Re-engineering conventional university education: Implications for students' learning styles. Distance Education, 21(2), 361384.

[34] Shaw, R.S. (2012). A study of the relationships among learning styles, participation types, and performance in programming language learning supported by online forums. Computers \& Education, 58, 111-120

[35] Şİrİn, A., \& GÜzel, A. (2006). The Relationship between Learning Styles and Problem Solving Skills among College Students. Educational Sciences: Theory \& Practice, 6(1).

[36] Slater, J. A., Lujan, H. L., \& DiCarlo, S. E. (2007). Does gender influence learning style preferences of first-year medical students. Advances in Physiology Education, 31, $336-342$.

[37] Smith, P.L., \& Ragan, T. J. (1999). Instructional design (2nd ed.). USA: John Wiley\& Sons, Inc.

[38] Stoll, L. And Fink, D. (1996) Changing our schools; linking school effectiveness and school improvement. Buckingham: Open University Press.

[39] Sun, K. T., Lin, Y. C., \& Yu, C. J. (2008). A study on learning effect among different learning styles in a Web-based lab of science for elementary school students. Computers \& Education, 50(4), 1411-1422.

[40] Terry, M. (2002). Translating learning style theory into developmental education practice: An article based on gregorc's cognitive learning styles. Journal of College Reading and Learning, 32(2), 154-176. doi:10.1080/10790195.2002.10850295.

[41] Topala, I. and Tomozii, S. (2014). Learning Satisfaction: Validity and Reliability Testing for Students' Learning Satisfaction Questionnaire (SLSQ). Procedia - Social and Behavioral Sciences; Procedia - Social and Behavioral Sciences, 128, pp. 380-386.

[42] Wolf, A. (2002). Does education matter?; myths about education and economic growth. London: London: Penguin. 